\title{
Effects of Ageratum conyzoides Leaf Decoction on Glucose Absorption in Rat's Small Intestine
}

\author{
Siti Sakinah, ${ }^{1}$ Diah Dhianawaty, ${ }^{2}$ Vita Murniati Tarawan ${ }^{3}$ \\ ${ }^{1}$ Faculty of Medicine Universitas Padjadjaran, Indonesia, ${ }^{2}$ Department of Biomedical Sciences \\ Faculty of Medicine Universitas Padjadjaran Bandung, Indonesia, ${ }^{3}$ Department of Biomedical \\ Sciences Faculty of Medicine Universitas Padjadjaran Bandung, Indonesia
}

\begin{abstract}
Background: Obesity is one of the health problems caused by excessive glucose intake which exceeds normal body requirement. To prevent health problems, Indonesian natives used traditional herbs, such as Ageratum conyzoides (billygoat weeds). The study aimed to discover the effect of Ageratum conyzoides leaf decoction on glucose absorption in the small intestine of rats.

Methods: An experimental study was conducted at the Biochemical Laboratory of Faculty of Medicine, Universitas Padjadjaran. Two groups of six rats were given Ageratum conyzoides leaf decoction with dosages 0.89 and $1.33 \mathrm{~g} / \mathrm{kgbw}$ respectively. Each rat was given glucose solution as a control, decoction administration along with the glucose solution, and glucose solution again to discover the effect of decoction in the absorption function after the administration of decoction was discontinued. Glucose absorbed by the intestine was measured every 15 minutes in 1 hour after the administrationof the solution.

Results: Glucose absorption was impeded in dosage 1 and 2 with a mean of the gap between glucose absorbed concentration before given decoction and after given decoction were 73.97 and $45.09 \mathrm{mg} /$ dl respectively. Analysis using paired t-test resulted in insignificant meaning (p-value of dosage $0.89 \mathrm{~g} /$ $\mathrm{kgbw}=0.08$; $\mathrm{p}$-value of dosage $1.33 \mathrm{~g} / \mathrm{kgbw}=0.06$ ). In the last glucose perfusion, absorption increased in both dosages after administration of decoction was discontinued.

Conclusions: Ageratum conyzoides leaf decoctioncan inhibit the glucose absorption in the small intestine but is not statistically significant. Further investigation may be needed by using a higher concentration of Ageratum conyzoides and/or other filtration methods.
\end{abstract}

Keywords: Ageratum conyzoides, glucose absorption, leaves decoction

\section{Introduction}

Glucose is a molecule utilized inside the human body as the primary source of energy. ${ }^{1}$ Glucose absorption occurs in the small intestine using secondary active transport via sodium and cotransporter sodium-glucose transporter-1 (SGLT-1) and therefore enters the bloodstream via glucose transporter-2 (GLUT-2) transporter. ${ }^{2}$ Excess of unused glucose is stored in various forms, and one of them is triglyceride. ${ }^{3}$ Further accumulation of triglyceride might cause health problems such as obesity. ${ }^{4,5}$ Obesity may become co-morbid of cardiovascular and metabolic disease. ${ }^{5}$

The use of herbal medicine is considered common in Indonesia. The Riset Kesehatan Dasar (or Basic Health Research) data published in 2013 stated that 49\% of
Indonesian population utilize herbal and traditional medicine (jamu) which are mostly used $(52.7 \%)$ to maintain health and fitness. ${ }^{6}$ One of the plants used as medicinal herb is the billygoat weeds (Ageratum conyzoides). Ageratum conyzoides is originated from the tropical area of America and spread worldwide, in both the subtropics and tropical regions. ${ }^{7}$ Ageratum conyzoides is known for its antihyperglycemic effect in rats by increasing the production of insulin. ${ }^{8}$ Ageratum conyzoides also contains active substrates such as alkaloids, flavonoid, triterpen, volatile, chromen, chromone, etc. ${ }^{9}$ Flavonoid, triterpen and alkaloids are known for their antihyperglycemic effect. ${ }^{10-13}$ Flavonoid impedes glucose absorption by blocking the GLUT-2 transporter in the small intestine. ${ }^{14}$ From these active substrate contained inside, it is highly expected that Ageratum conyzoides

Correspondence: Siti Sakinah, Faculty of Medicine, Universitas Padjadjaran, Jalan Raya Bandung-Sumedang KM 21, Indonesia, Email: sitisakinah1598@yahoo.co.id 
might impede the absorption of glucose in the small intestine, so that excess glucose stored in the adipocytes might be reduced. This study was conducted to discover the effect of Ageratum conyzoides leaf decoction towards glucose absorption in the small intestine of rats and also determine the amount of dosage which brought out the impact if the effect proved to exist.

\section{Methods}

Alaboratory experimentalstudywas conducted in the biochemical laboratory located at the Faculty of Medicine, Universitas Padjadjaran, Jatinangor, and used the experimental study design. This study was approved by the Health Research Ethics Committee of Faculty of Medicine, Universitas Padjadjaran, No: 810/ UN6.C1.3.2/KEPK/PN/2016. Study subjects were 12 homogenous male Wistar rats (Rattus norvegicus). The number of subjects was calculated using Mead Resource Equation. Inclusion criteria for the rats were: in the age of 3-4 months, weighing 250-300 grams, and was considered as healthy (moving actively and did not have any injury). Exclusion criteria were rats with deteriorating health status, which was characterized as having reduction in mobility, decreasing bodyweight until $m>10 \%$, secretion of porfirin pigment around eyes and nose region appeared as red crust, rats that were unable to adapt, and death.
Another exclusion criterion was rats that had been used as subject in an earlier project.

Ageratum conyzoides was collected from Solo, Central Java, Indonesia, and then extracted using the decoction method. The process was preceded firstly with the washing and drying process of the Ageratum conyzoides leaves before it was powdered. Distilled water was added and then it was stirred homogenously. The mixture was then heated for 30 minutes to a temperature of $90^{\circ} \mathrm{C}$. After that, the heated mixture was filtered and distilled water was added until it reached the required volume.

The study subjects were undergoing the adaptation process for 7 days in the Biochemical Laboratory at the Faculty of Medicine, Universitas Padjadjaran. Rats that were unable to adapt were excluded, while rats that were able to adapt for 7 days were enrolled in the study as the study subjects. The study subjects were firstly anesthetized using Ketamine with the dosage of $0.13 \mathrm{mg} / 100$ gram per bodyweight. After the anesthetic drug took effect, the rats were fixated on the preparation board. The abdomen of the rat was sliced open starting from the skin, layer by layer, until it reached the small intestine and then it was removed from the body. The cannula from the perfusion set was inserted until it reached $\pm 10 \mathrm{~cm}$ beyond the pylorus and $25 \mathrm{~cm}$ after. After that, the small intestine was washed using $\mathrm{NaCl} 0.9 \%$. Two cannulas tied together on the intestine were connected

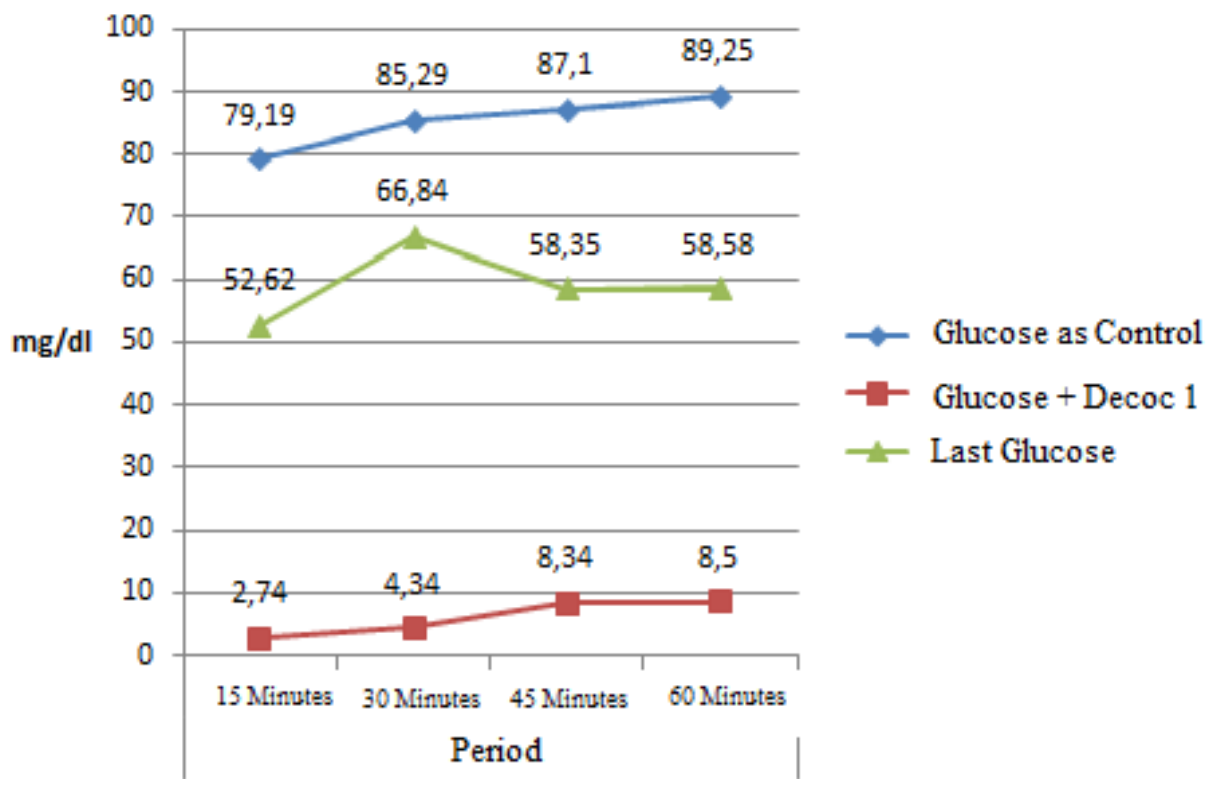

Figure 1 Mean of Glucose Absorbed Concentration in Group 1 
to the perfusion set using a small tube. Then, liquid was administered into the small intestine using the perfusion set.

The study subjects were classified into two groups with six rats in each group based on different dosages. Every subject was given control intervention, which was the administration of $3 \mathrm{mM}$ glucose for 1 hour and sample data collection every 15 minutes from the liquid in the small tube of the perfusion set. The second intervention was given 1 hour after the control intervention, which was the administration of glucose solution with different dosages of the leaves decoction in each group, with the same data collection method as the earlier control intervention. In the last 1 hour, $3 \mathrm{mM}$ glucose solution was again administered as the third intervention to observe the recovery effect of the leaf decoction, and sample data was collected every 15 minutes from the liquid in the small tube of the perfusion set. The first group was given a dosage of $0.89 \mathrm{~g} / \mathrm{kgbw}$ and the latter was given $1.33 \mathrm{~g} / \mathrm{kgbw}$.

Glucose concentration measurement was conducted by taking $50 \mu \mathrm{l}$ sample, and then underwent a deproteinization process using 8\% TCA as much as $500 \mu \mathrm{l}$, continued with $3000 \mathrm{rpm}$ centrifugation for 10 minutes. The supernatant was taken as much as 100 $\mu \mathrm{l}$ and then mixed with $1 \mathrm{ml}$ ofreagent. The mixtures were then incubated for 10 minutes in a temperature of $37^{\circ} \mathrm{C}$. Absorbance was examined using the spectrophotometer with $505 \mathrm{~nm}$ wavelength. Glucose concentration was measured using the ST Reagensia formula. The result was then converted into glucose concentration which described the amount absorbed.

The data was then analyzed using the Shapiro-Wilk test for normality test and paired t-test for statistical test. The result was considered as significant if the value of $\mathrm{p} \leq 0.05$.

\section{Results}

The mean of glucose absorbed by rats in the first group with the entire subject of four rats (Figure 1). The results were extracted from the measurement of each rat's sample every 15 minutes for 1 hour after the consecutive administration of three interventions. In the control intervention, the glucose absorption increased in each measurement (in the first 15 minutes until the fourth). Glucose accompanied by decoction as much as 0.8928 $\mathrm{g} / \mathrm{kgbw}$ was administered after 1 hour, and the result showed a decrease in absorption of glucose at the small intestine compared to the control intervention (without decoction administration). It could be determined that the absorption impeded in rats which were given the decoction. Lastly, 1 hour after the second intervention, the rats were given the glucose

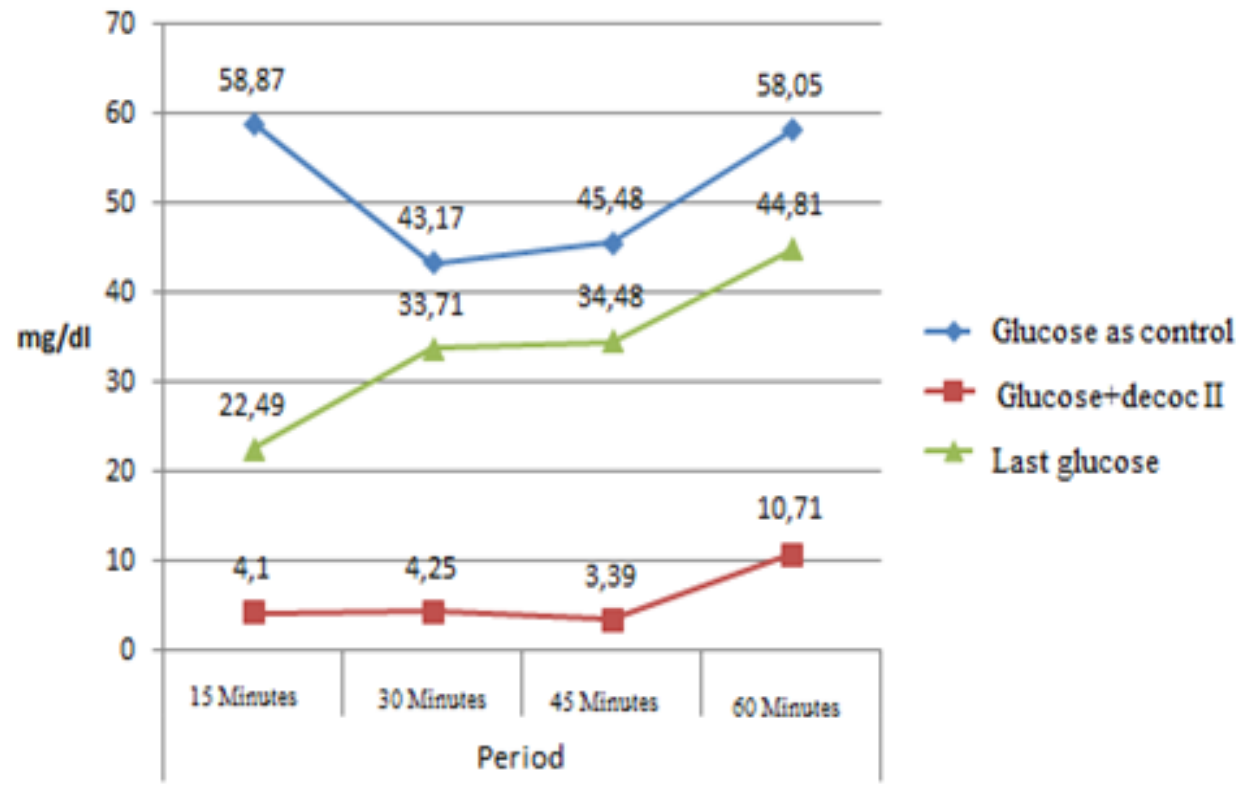

Figure 2 Mean of Glucose Absorbed Concentration in Group 2 
Table 1 Normality Tests (Shapiro-Wilk)

\begin{tabular}{|c|c|c|c|c|c|}
\hline Group & Rats & $\begin{array}{l}\text { Mean of glucose } \\
\text { in control } \\
\text { intervention for } 1 \\
\text { hour in each rats } \\
(\mathrm{mg} / \mathrm{dl})\end{array}$ & $\begin{array}{c}\text { Mean of glucose } \\
+ \text { decoct for } 1 \\
\text { hour in each } \\
\text { rats (mg/dl) }\end{array}$ & $\begin{array}{c}\text { Mean of end last } \\
\text { glucose for } 1 \\
\text { hour in each rats } \\
(\mathrm{mg} / \mathrm{dl})\end{array}$ & Normal value \\
\hline \multirow[t]{4}{*}{1} & A & 165.46 & 9.54 & - & \multirow{4}{*}{$\begin{array}{l}\text { Glucose in control }=0.24^{*} \\
\text { Glucose }+ \text { decoct }=0.37^{*}\end{array}$} \\
\hline & B & 47.87 & 2.65 & - & \\
\hline & $\mathrm{C}$ & 75.00 & 9.25 & - & \\
\hline & D & 34.99 & 5.98 & - & \\
\hline \multirow[t]{4}{*}{2} & E & 41.83 & 3.76 & - & \multirow{4}{*}{$\begin{array}{l}\text { Glucose in control }=0.17^{*} \\
\text { Glucose }+ \text { decoct }=0.23^{*}\end{array}$} \\
\hline & $\mathrm{F}$ & 94.62 & 5.13 & - & \\
\hline & $\mathrm{G}$ & 42.80 & 10.70 & - & \\
\hline & $\mathrm{H}$ & 26.33 & 5.61 & - & \\
\hline \multirow[t]{4}{*}{1} & A & 165.46 & - & 48.36 & \multirow{4}{*}{$\begin{array}{l}\text { Glucose in control }=0.09^{*} \\
\text { Last glucose }=0.06^{*}\end{array}$} \\
\hline & B & 47.87 & - & 34.98 & \\
\hline & $\mathrm{C}$ & 75.00 & - & 111.20 & \\
\hline & D & 34.99 & - & 41.86 & \\
\hline \multirow[t]{4}{*}{2} & E & 41.83 & - & 55.07 & \multirow{4}{*}{$\begin{array}{l}\text { Glucose in control }=0,17^{*} \\
\text { Last glucose }=0,26^{*}\end{array}$} \\
\hline & $\mathrm{F}$ & 94.62 & - & 3.59 & \\
\hline & $\mathrm{G}$ & 42.80 & - & 56.23 & \\
\hline & $\mathrm{H}$ & 26.33 & - & 20.61 & \\
\hline
\end{tabular}

Note: * data was normally distributed

solution as the third intervention to observe the reversible effect of absorption reduction influenced by decoction administration. Glucose absorption in the first 15 minutes until the fourth showed a decrease of absorption blockage effect of Ageratum conyzoides leaves after the decoction administration was discontinued.

The mean of absorbed glucose in the second group of four rats that were given three interventions (Figure 2) showed that in the control glucose intervention, there was an increase in glucose absorption in every 15 minutes of measurements. The second intervention was given after 1 hour, which was the mixture of glucose and decoction with a dosage of $1.33 \mathrm{~g} / \mathrm{kgbw}$. The measurement for every 15 minutes showed a decreasing trend compared to glucose absorption in the earlier first hour, and so the result revealed that there was an absorption blockage effect after the administration of decoction. Lastly, 1 hour after the second intervention, the rats were given the glucose solution again to observe the reversible effect of absorption blockage influenced by decoction administration. The result from the last intervention showed that the absorption blockage effect was reduced after the discontinuation of decoction administration.

Normality tests and statistical data analysis of the results was conducted four times (Table 3 and 4). The normality test showed normal distribution in all data with normal value $>0.05$. The first and second analyses compared the mean of glucose in the control and glucose+decoction with two different dosages: the first dosage was $0.89 \mathrm{~g} / \mathrm{kgbw}$ and the second was $1.33 \mathrm{~g} / \mathrm{kgbw}$, in order to observe the significance of the blockage effect. The administration of the leaf decoction was found to have an absorption blockage effect, even though it was not statistically significant $(p \leq 0.05)$. The third and fourth analyses were conducted to find the ratio of glucose absorption in the control intervention and glucose administration after the decoction administration in both groups, group 1 and 2 , and the result found was not considered as significant $(p \leq 0.05)$. This finding could determine that the glucose absorption before and after the administration of the decoction 
Table 2 Statistical Data Analyses

\begin{tabular}{|c|c|c|c|c|c|}
\hline Group & Rats & $\begin{array}{l}\text { Mean of glucose } \\
\text { in control } \\
\text { intervention for } 1 \\
\text { hour in each rats } \\
(\mathrm{mg} / \mathrm{dL})\end{array}$ & $\begin{array}{l}\text { Mean of glucose } \\
+ \text { decoct for } 1 \\
\text { hour in each } \\
\text { rats }(\mathrm{mg} / \mathrm{dL})\end{array}$ & $\begin{array}{c}\text { Mean of end last } \\
\text { glucose for } 1 \\
\text { hour in each rats } \\
(\mathrm{mg} / \mathrm{dL})\end{array}$ & $P$ value \\
\hline \multirow[t]{4}{*}{1} & A & 165.46 & 9.54 & - & \multirow{4}{*}{$0.08^{*}$} \\
\hline & B & 47.87 & 2.65 & - & \\
\hline & $\mathrm{C}$ & 75.00 & 9.25 & - & \\
\hline & $\mathrm{D}$ & 34.99 & 5.98 & - & \\
\hline \multirow[t]{4}{*}{2} & E & 41.83 & 3.76 & - & \multirow{4}{*}{$0.059 *$} \\
\hline & $\mathrm{F}$ & 94.62 & 5.13 & - & \\
\hline & G & 42.80 & 10.70 & - & \\
\hline & $\mathrm{H}$ & 26.33 & 5.61 & - & \\
\hline \multirow[t]{4}{*}{1} & A & 165.46 & - & 48.36 & \multirow{4}{*}{$0.479^{* *}$} \\
\hline & B & 47.87 & - & 34.98 & \\
\hline & $\mathrm{C}$ & 75.00 & - & 111.20 & \\
\hline & D & 34.99 & - & 41.86 & \\
\hline \multirow[t]{4}{*}{2} & E & 41.83 & - & 55.07 & \multirow{4}{*}{$0.533^{* *}$} \\
\hline & $\mathrm{F}$ & 94.62 & - & 3.59 & \\
\hline & G & 42.80 & - & 56.23 & \\
\hline & $\mathrm{H}$ & 26.33 & - & 20.61 & \\
\hline
\end{tabular}

only showed a slight difference, meaning that glucose absorption returned as being quite high even after the administration of decoction.

\section{Discussion}

Absorption blockage inflicted by two different dosages of Ageratum conyzoides leaf decoction was stated earlier in the previous study, which stated that one of the active substances inside the leaves, flavonoid, had a non-competitive inhibitor role towards GLUT-2 transporter. ${ }^{14}$ A similar finding was found in this study, even though the finding was not significant. In this study the mean of the gap between glucose absorbed concentration before given treatment and after given treatment in group 1 and 2 respectively were $73.97 \mathrm{mg} / \mathrm{dl}$ and $45.09 \mathrm{mg} / \mathrm{dl}$. The insignificant result might be caused by the inaccuracy of the dosage or limited concentration of the active substance which was able to block glucose absorption contained in the preparation used in this study.

An increase in glucose absorption after the cessation of decoction administration in both groups was also found in a previous study, which states that flavonoid is a noncompetitive inhibitor. ${ }^{14}$ This is one of the reversible inhibitors which is able to retrieve blocked function after the cessation of given inhibitory intervention.

This study also has several limitations, including the limitation of time. The limited time for conducting the study caused the inability of examining the samples right after the samples were obtained. During this period, from sample collection until sample measurements, there possibly occurred changes which influenced the glucose concentration or other physical changes which may alter the study. Ketamine used in this study is known for having an effect of decreasing the absorption ability of the intestine which may affect the result of the study.15 The contamination of instruments used for sample placements might also influence the measurement results. This limitation was suspected as the cause of ineligibility for the subjects to be enrolled in the study, so that the minimum sample size was not achieved (total subject for two groups had to be 12) since only 8 rats were able to fulfill the criteria because 
of this factor. The remaining rats were not included in the equation due to its condition which did not fitt in the glucose absorption theory where it must be in a positive value, while they were in a negative value).

It can be concluded that leaves decoction of Ageratum conyzoides in the dosage of 0.89 and $1.33 \mathrm{~g} / \mathrm{kgbw}$ inhibit the glucose absorption in the small intestine of rats, eventhough the finding is not statistically significant $(p \leq 0.05)$

The suggestion for further studies is to encourage the advance glucose absorption blockade test using Ageratum conyzoides extract with other filtration method and/or higher concentration. This plant could be used as herbal medicine to prevent obesity in the further studies.

\section{References}

1. Gailliot MT, Baumeister RF, Dewall CN, Maner JK, Plant EA, Tice DM, et al. Selfcontrol relies on glucose as a limited energy source:willpower is more than a metaphor. J Pers Soc Psychol. 2007;92(2):325-36.

2. Sherwood L. Human physiology: from cells to systems. $8^{\text {th }}$ ed. Pacific Grove, California: Brooks/Cole; 2015.

3. Bouret S, Levin BE, Ozanne SE. Controlling energy and glucose homeostasis and the developmental origins of obesity genetic basis of obesity. Am Physiol Soc. 2015;95(1):47-82.

4. Goldberg IJ. Triglyceride: one molecule at the center of health and disease. BBA - Mol Cell Biol Lipids. 2012;1821(5):719-20.

5. Klop B, Elte JWF, Cabezas MC. Dyslipidemia in obesity: mechanisms and potential targets. Nutrients. 2013;5(4):1218-40.

6. Kementerian Kesehatan Republik Indonesia. Riset Kesehatan Dasar 2013.
Jakarta: Kementerian Kesehatan Republik Indonesia; 2013.

7. Nasrin F. Antioxidant and cytotoxic activities of Ageratum conyzoides stems. Int Curr Pharm J. 2013;2(2):33-7.

8. Nyunai N, Abdennebi E, Bickii J, ManguellaDicoum MA. Subacute antidiabetic properties of Ageratum conyzoides leaves in diabetic rats. Int J Pharm Sci Res. 2015;6(4):1378-87.

9. Pharm IJ, Res P, Shekhar TC, Anju G. A comprehensive review on Ageratum conyzoides linn.(goat weed). Int J Pharm Phytopharm Res. 2012;1(6):391.

10. Liu X, Zhu L, Tan J, Zhou X, Xiao L, Yang X, et al. Glucosidase inhibitory activity and antioxidant activity of flavonoid compound and triterpenoid compound from Agrimonia pilosa ledeb. BMC Complement Altern Med. 2014;14(1):1-10.

11. Singh SB, Devi WR, Marina a, Devi WI, Swapana N, Singh CB. Ethnobotany , phytochemistry and pharmacology of Ageratum conyzoides Linn (Asteraceae ). J Med Plants Res. 2013;7(8):371-85.

12. Mosa R, Cele N, Mabhida S, Shabalala S, Penduka D, Opoku A. In vivo antihyperglycemic activity of a Lanosteryl triterpene from Protorhus longifolia. Molecules. 2015;20(7):13374-83.

13. Babu PVA, Liu D, Gilbert ER. Recent advances in understanding the antidiabetic actions of dietary flavonoids. J Nutr Biochem. 24(11):1777-89.

14. Kwon O, Eck P, Chen S, Corpe CP, Lee J-H, Kruhlak M, et al. Inhibition of the intestinal glucose transporter GLUT2 by flavonoids. FASEB J. 2007;21(2):366-77.

15. Grifiin B, O’Driscoll C. Drug absorption studies in situ, in vitro and in silico models. In: Ehrhardt C, Kim K-J, editors. $1^{\text {st }}$ ed. New York: Spring; 2008. 